\title{
Growth and sustainability of Suaeda salsa in the Lop Nur, China
}

\author{
LI Congjuan ${ }^{1}$, LIU Ran ${ }^{2 *}$, WANG Shijie ${ }^{1}$, SUN Yongqiang ${ }^{1}$, LI Shengyu ${ }^{1}$, ZHANG Heng ${ }^{1}$, \\ GAO Jie ${ }^{1}$, DANG Yanxi ${ }^{3}$, ZHANG Lili $^{4}$ \\ ${ }^{1}$ National Engineering Technology Research Center for Desert-Oasis Ecological Construction, Xinjiang Institute of Ecology \\ and Geography, Chinese Academy of Sciences, Urumqi 830011, China; \\ ${ }^{2}$ State Key Laboratory of Desert and Oasis Ecology, Xinjiang Institute of Ecology and Geography, Chinese Academy of \\ Sciences, Urumqi 830011, China; \\ ${ }^{3}$ Singapore Deposit Insurance Corporation (SDIC) Xinjiang Luobupo Potash Co. Ltd., Urumqi 839000, China; \\ ${ }^{4}$ Tarim Branch, PetroChina Company Limited, Korla 841000, China
}

\begin{abstract}
Extremely saline soils are very harsh environments for the growth and survival of most plant species, however, halophytes can grow well. The underlying mechanism of halophyte to resist high saline is not well understood by us. This study was conducted at the potash mine near the Lop Nur, China, where the effects of the halophyte Suaeda salsa L. on the saline-alkaline soils and its growth and sustainability were investigated. Four plots (in which the salt encrustation layers were removed), with different soil treatments were evaluated: (1) undisturbed soil, with no additional treatment (T1); (2) the slag soil zone, in which a $40-\mathrm{cm}$ layer of slag was placed on the undisturbed soil surface (T2); (3) slag+sandy soil, in which a 20 -cm layer of slag was placed in the lower layer and $20 \mathrm{~cm}$ of sandy soil, taken from an area about $70 \mathrm{~km}$ away from Lop Nur potash mine, where Tamarix species were growing, was placed in the upper layer (T3); and (4) a 40-cm sandy soil layer taken from the area where Tamarix species were growing was placed on undisturbed soil (T4). Soil nutrient contents increased in the four treatments, but salt content only decreased in the T1 treatment. Salt content in the T4 treatment increased over the two-year period, which may be partly attributed to salt deposition from wind-blown dust within the mine and salt accumulation within the surface soil $(0-20 \mathrm{~cm})$ in response to high evaporative demands. The $S$. salsa plants exhibited greater improvements in growth under the T4 treatment than under the T1, $\mathrm{T} 2$, and T3 treatments, which demonstrated that low levels of salinity are beneficial for the growth of this species. The T1 treatment was sustainable because of its low cost and superior soil improvement characteristics. Therefore, $S$. salsa plants not only reduced soil salinity and increased soil nutrient levels, but also ameliorated the plant growth environment, which would be beneficial for both the ecological restoration of the Lop Nur area and similar areas throughout the world.
\end{abstract}

Keywords: Suaeda salsa; saline-alkaline soil; plant-soil interaction; sustainability; Lop Nur

Citation: LI Congjuan, LIU Ran, WANG Shijie, SUN Yongqiang, LI Shengyu, ZHANG Heng, GAO Jie, DANG Yanxi, ZHANG Lili. 2018. Growth and sustainability of Suaeda salsa in the Lop Nur, China. Journal of Arid Land, 10(3): 429-440. https://doi.org/10.1007/s40333-018-0002-5

\section{Introduction}

Soil salinization is a worldwide problem that reduces the area suitable for cultivation and degrades ecosystems (Mondal, 2001; Miyamoto et al., 2005; Yavitt et al., 2009). Consequently,

*Corresponding author: LIU Ran (E-mail: liuran@ms.xjb.ac.cn)

Received 2017-09-29; revised 2017-12-21; accepted 2018-01-17

C Xinjiang Institute of Ecology and Geography, Chinese Academy of Sciences, Science Press and Springer-Verlag GmbH Germany, part of Springer Nature 2018 
there is much interest in finding low-input and sustainable methods of reducing soil salinity and alkalinity; thus, improving soil quality (Metternicht and Zinck, 2003). Halophytes are effective for improving saline soils (Tian et al., 2004), occur naturally in high salinity areas, and can survive well in strongly saline-alkaline soils (Darwish et al., 2005; Liang et al., 2005; Tejada et al., 2006; Zhu et al., 2012). They are abundant in nature, and can tolerate higher levels of salt stress than glycophytes (Tejada and Gonzalez, 2005). The planting of halophytes has recently received much attention because of increasing soil salinization and the global shortage of freshwater (Khan and Weber, 2006; Duan et al., 2007).

Lop Nur, the central catchment area of the Tarim Basin, China, is in the eastern part of the basin at an elevation of $780 \mathrm{~m}$ a.s.l. The climate is extremely dry, annual precipitation is $20 \mathrm{~mm}$, and the annual evaporation is $2901 \mathrm{~mm}$ (Xia et al., 2007). The soil is generally covered by a hard salt crust, and there are no surface water resources except for a few salty springs and some temporary seepage areas following rainstorms in the piedmont zone. Some areas within the basin contain large quantities of potash that were found at the end of the 1990s. A large potash mine (Singapore Deposit Insurance Corporation (SDIC) Xinjiang Luobupo Potash Co. Ltd.) began operating within the basin in 2002, in an area characterized by extreme drought, which has about $80 \mathrm{~cm}$ of salt encrustation at the soil surface and $>30 \%$ salt content in the under layer. The area experiences large quantities of saline dust and large seasonal temperature variations. The soils generally have low nutrient levels, and together with the other previously mentioned factors, this results in a harsh environment for plant growth and survival (Zhao et al., 2006). Therefore, the salt encrustation layer must be eradicated, and it is hypothesized that planting halophytic plants in such an extreme high-salinity area would not only play an important role in improving the ecological environment but also significantly improve the soil.

Growing plants in saline and sodic soils is an emerging, low-cost method of remediation. Halophytic plants grow naturally in salinized areas, and can survive in salt concentrations equal to or greater than those found in seawater. The re-vegetation of salinized areas with halophytic plants is an example of proactive phytoremediation (Song and Wang, 2015). The use of the halophytic succulent annual herb Suaeda salsa L. in the recovery of saline soils has previously been demonstrated (Zhao et al., 2002; Cheng et al., 2014; Song and Wang, 2015). S. salsa is an annual euhalophytic herb, with a high salt tolerance during seed germination and the seedling stages (Song et al. 2011; Wang et al., 2015; Xu et al., 2016; Zhou et al., 2016; Song et al., 2017). $S$. salsa is the most effective plant species for facilitating the leaching of salts from the rhizosphere in arid and semi-arid regions, where the rainfall is low (Zhao et al., 2003; Song and Wang, 2015). The shoots and seeds of this species contain relatively high levels of protein and unsaturated fatty acids, which may be beneficial for the restoration of soil health (Zhao, 1991; Wang et al., 2015). Planting S. salsa on saline-alkaline soils has not only been shown to help reduce soil salt content but also increases soil organic matter and nutrient levels (Zhang et al., 1998).

Several previous studies have addressed the problem of salt toxicity and the need for saline soil improvement (Liang et al., 2005; Tejada and Gonzalez, 2005; Ashraf et al., 2008; Uddin et al., 2009; Song and Wang, 2015), but they have generally focused on coastal saline soils, with few studies conducted on the soils of the Lop Nur hinterland. The purpose of this study was to address this knowledge gap. The study objectives were to: (1) evaluate the growth and survival of $S$. salsa in the harsh soil and climatic conditions of the Lop Nur hinterland; (2) determine the effects of growing $S$. salsa on the saline-alkaline soils that are typical of the Lop Nur potash mine area; and (3) evaluate the effects of different soil saline conditions on plant growth and the sustainability of the different treatments.

\section{Materials and methods}

\subsection{Study area}

The study was conducted in the hinterland of Lop Nur $\left(40^{\circ} 22^{\prime} \mathrm{N}, 90^{\circ} 52^{\prime} \mathrm{E} ; 1152 \mathrm{~m}\right.$ a.s.1.; Fig. 1), which is an extremely arid area. According to meteorological records taken at the weather station 
in Ruoqiang County from the last 15 years, the climate in the lake area of Lop Nur is very severe, with annual precipitation averaging less than $20 \mathrm{~mm}$ and annual evaporation averaging more than $3000 \mathrm{~mm}$. Within a year, there are 102.5 days on average that have winds sufficiently strong to cause dust storms, and there are 18.6 days on average that have winds exceeding Beaufort force 8 . The area was once described as the world's most desolate area, with the exception of the two polar regions (Chen, 1936; Fig. 2). No living organisms were found in this area before the construction of the potash mine in 2002 due to the extreme environment of the deep salt encrustation layer, while more than 3000 workers have worked there since the SDIC Xinjiang Luobupo Hoevellite Co., Ltd., mining facility was completed. Because it is a working mine, full restoration of the environment is impossible, thus, planting halophytes becomes the only possible soil improvement procedure.

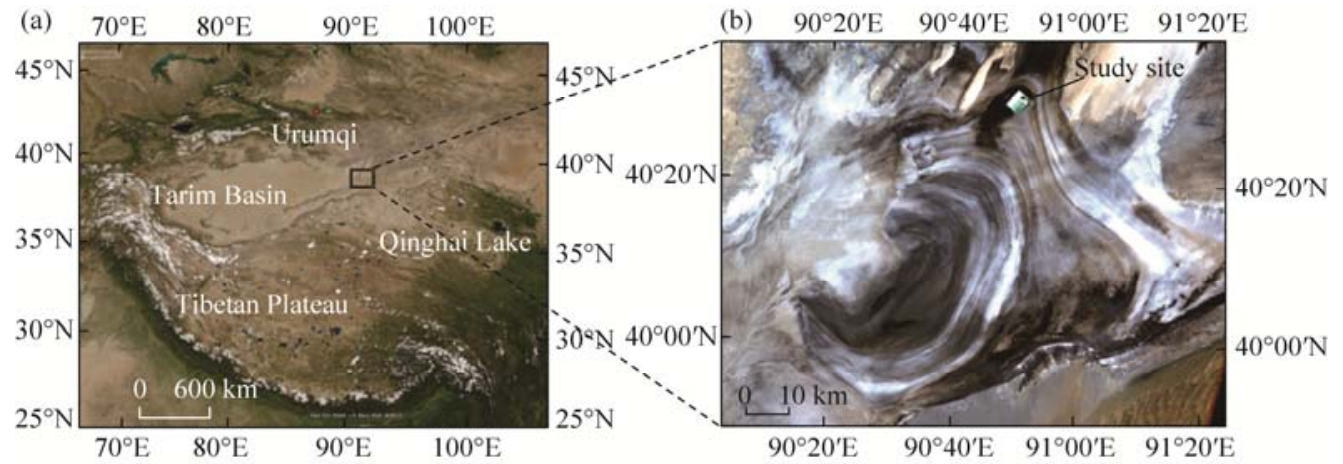

Fig. 1 Locations of the Lop Nur and the study site

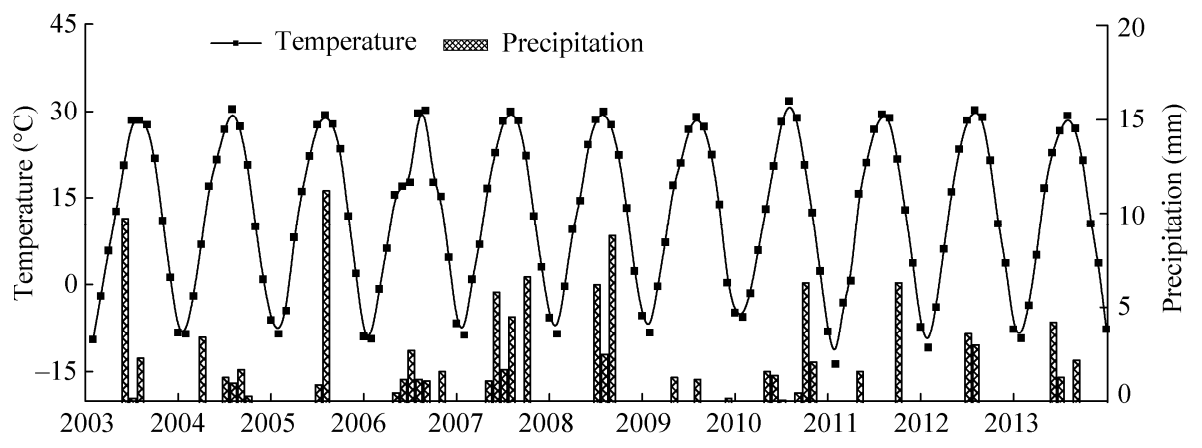

Fig. 2 Monthly average temperature and monthly precipitation at the study site

\subsection{Experimental design}

The experiment was conducted at an artificial ecological vegetation demonstration area near the mine. An experimental area $(60 \mathrm{~m} \times 5 \mathrm{~m})$ was divided into four plots of $15 \mathrm{~m} \times 5 \mathrm{~m}$. To ensure the survival of artificial plants and to reduce investment, we covered the soil surface with $80 \mathrm{~cm}$ of a salt encrustation layer. The materials used were sourced from close to the potash mine, with slag collected from the power station operated by the mine and the sandy soil collected from the nearest area where plants (Tamarix species) could survive, which was about $70 \mathrm{~km}$ away from the potash mine. Prior to the initiation of the experiment, we removed the salt crust and randomly applied four experimental treatments to each of the four plots. The treatments were as follows: (1) undisturbed soil, with no additional treatment (T1); (2) the slag-soil zone, in which a 40-cm layer of slag was placed on the undisturbed soil surface (T2); (3) slag+sandy soil, in which a 20-cm layer of slag was placed in the lower layer and $20 \mathrm{~cm}$ of sandy soil taken from the area where Tamarix species were growing was placed in the upper layer (T3); and (4) a 40-cm sandy soil layer taken from the area where Tamarix species were growing was placed on undisturbed soil (T4). The chemical properties of the different soil types are presented in Table 1. The undisturbed 
soil had high salt and low nutrient levels, while the slag and soil taken from the Tamarix growing area had low salinity.

In early May 2013 and 2014, S. salsa seeds were sown at a density of $15 \mathrm{~kg} / \mathrm{hm}^{2}$ in the four plots. The same irrigation and management models were applied in the four plots. Drip irrigation with freshwater was applied for $2 \mathrm{~h}$ every five days from May to June, and every three days from July to September, respectively. The amount of irrigation was equivalent to about $7 \mathrm{~mm}$ precipitation.

Table 1 Chemical properties of the different soil types

\begin{tabular}{cccccccr}
\hline Soil type & $\mathrm{pH}$ & $\begin{array}{c}\mathrm{EC} \\
(\mathrm{mS} / \mathrm{cm})\end{array}$ & $\begin{array}{c}\text { Total salt } \\
(\mathrm{mg} / \mathrm{g})\end{array}$ & $\begin{array}{c}\mathrm{SOC} \\
(\mathrm{g} / \mathrm{kg})\end{array}$ & $\begin{array}{c}\mathrm{TN} \\
(\mathrm{g} / \mathrm{kg})\end{array}$ & $\begin{array}{c}\mathrm{TP} \\
(\mathrm{g} / \mathrm{kg})\end{array}$ & $\begin{array}{c}\mathrm{TK} \\
(\mathrm{g} / \mathrm{kg})\end{array}$ \\
\hline Undisturbed soil & 8.93 & 61.30 & 295.16 & 1.45 & 0.074 & 0.18 & 8.72 \\
Slag & 8.38 & 5.43 & 49.25 & 7.22 & 0.110 & 0.23 & 20.58 \\
Sandy soil & 7.86 & 2.07 & 14.89 & 1.59 & 0.080 & 0.19 & 7.98 \\
\hline
\end{tabular}

Note: EC, electrical conductivity; SOC, soil organic carbon; TN, total nitrogen; TP, total phosphorus; TK, total potassium.

\subsection{Soil and plant sampling}

Soil samples from 0 to $20 \mathrm{~cm}$ layer were collected from each plot at the beginning of 2013 prior to planting S. salsa, and later in 2013 and 2014 after S. salsa had been harvested. Soil samples were taken from areas, 10-20-cm away from the plants rather than from the rhizosphere, because a salt island may exist, which could result in ion exclusion by roots. There were five replications of each soil sample. Fifteen plants in each plot were randomly selected for measurements of plant height, crown length, and crown width on 8 July, 28 July, and 14 August, 2014. The plants were harvested on 25 and 26 August, and above- and below-ground biomass measurements were taken. The biomass (fresh weight) in a $1-\mathrm{m}^{2}$ representative area of each of the five replicates was measured in every treatment plot, and the plant samples were then dried in a drying oven at $60^{\circ} \mathrm{C}$ for $24 \mathrm{~h}$ to estimate the yield per hectare, and then stored for later chemical analysis of their salt and salt ion contents.

\subsection{Sample analysis}

The soil chemical properties and plant salts were analyzed after the soil was air-dried and hand-sieved using a $0.25-\mathrm{mm}$ mesh to remove roots and other debris. Soil electrical conductivity (EC) and $\mathrm{pH}$ were determined using a conductivity bridge $(\mathrm{dS} / \mathrm{m})$ and a glass electrode $\mathrm{pH}$ meter (Fresenius et al., 1988), respectively. Soil and plant chloride $\left(\mathrm{Cl}^{-}\right)$, sulfate $\left(\mathrm{SO}_{4}{ }^{2-}\right)$, and bicarbonate radical $\left(\mathrm{HCO}_{3}{ }^{-}\right)$contents were determined using ion chromatography (Hucoa-Erloss, 2000I/SP, Dionex, Sunnyvale, California). Calcium $\left(\mathrm{Ca}^{2+}\right)$ and magnesium $\left(\mathrm{Mg}^{2+}\right)$ contents were measured using a disodium dihydrogen ethylenediaminetetraacetate (EDTA) extraction followed by a murexide indicator for calcium and an eriochrome black $\mathrm{T}$ indicator for the combined calcium and magnesium contents. Sodium $\left(\mathrm{Na}^{+}\right)$and potassium $\left(\mathrm{K}^{+}\right)$contents were determined by atomic absorption spectrometry (1100B, PerkinElmer, Waltham, MA, USA). All the quantitative procedures were adapted from Patnaik (1997). Total dissolved salt contents were calculated by summing the number of anions and cations, and soil organic carbon (SOC) content was determined using the Walkley-Black $\mathrm{K}_{2} \mathrm{Cr}_{2} \mathrm{O}_{7}-\mathrm{H}_{2} \mathrm{SO}_{4}$ oxidation method (Nelson and Sommers, 1982). Total nitrogen (TN) was determined using the Kjeldahl procedure, with a UDK140 automatic steam distillation unit and a TitroLine 96 titration unit. Total phosphorus (TP) was determined by flow injection analysis (Nelson and Sommers, 1982) and total potassium (TK) was determined by the method of Nelson and Sommers (1982).

\subsection{Data analysis}

All the data analyses were performed using SPSS 17.0 software. An analysis of variance was conducted to determine the significance $(P<0.05)$ of differences in the mean values of soil properties between before and after planting in the different years within treatments, and biomass production and salt accumulation between treatments. Tukey's HSD (honest significant difference) 
was used for a comparison of means $(P<0.05)$. All results are presented as means plus or minus the standard error (SE). Origin 8.0 software was used to produce the figures.

\section{Results}

\subsection{Effects of plant treatments on soil chemical properties}

Soil $\mathrm{pH}, \mathrm{EC}, \mathrm{K}^{+}, \mathrm{Na}^{+}, \mathrm{Ca}^{2+}, \mathrm{Mg}^{2+}, \mathrm{Cl}^{-}, \mathrm{SO}_{4}{ }^{2-}, \mathrm{HCO}_{3}{ }^{-}$, and total salt contents decreased over the two planting years in the T1 treatment (Figs. 3 and 4), indicating that $S$. salsa plays an important role in reducing soil salinity and alkalinity. All the chemical properties of the undisturbed soil were significantly different from those of the other soil treatments. In the T4 treatment, soil $\mathrm{pH}$, $\mathrm{EC}, \mathrm{K}^{+}, \mathrm{Na}^{+}, \mathrm{Ca}^{2+}, \mathrm{Mg}^{2+}, \mathrm{Cl}^{-}, \mathrm{SO}_{4}{ }^{2-}, \mathrm{HCO}_{3}{ }^{-}$, and total salt contents increased over the two-year period, and were significantly different to those in the other treatments. It is possible that wind-blown dust from the mine area, which is characteristically high in mineral salts, and the high evaporation level, which is also a characteristic of this area, caused salt accumulation in the surface soil in quantities larger than the plants could absorb.
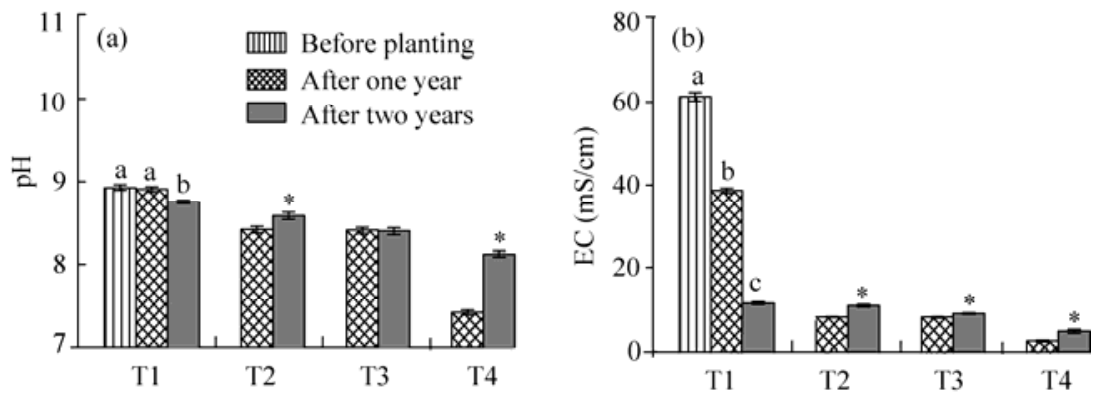

Fig. 3 Soil pH (a) and soil electrical conductivity (EC) (b) over a two-year period in an undisturbed soil with the salt crust layer removed and the following treatments applied to the soil surface: T1 (the salt layer removed and the soil left undisturbed), T2 (a 40-cm surface slag layer), T3 (a 20-cm slag layer placed below a 20-cm sandy soil layer), and T4 (a 40-cm surface sandy soil layer). Treatments of T1, T2, T3, and T4 are the same as in Figures 4-9. * indicates significant difference between years at $P<0.05$ level. Different lowercase letters indicate significant differences between years at $P<0.05$ level in the T1 treatment. Bars mean standard errors.
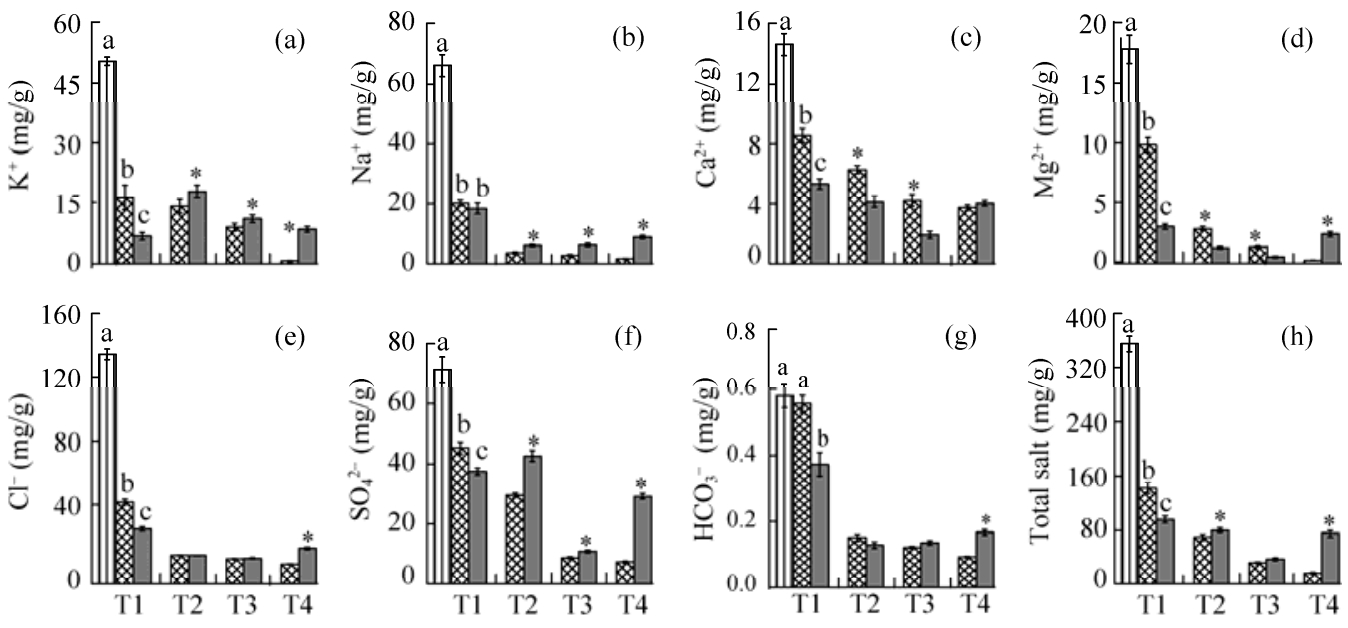

血血 Before planting After one year $\square$ After two years

Fig. 4 Contents of $\mathrm{K}^{+}$(a), $\mathrm{Na}^{+}$(b), $\mathrm{Ca}^{2+}$ (c), $\mathrm{Mg}^{2+}$ (d), $\mathrm{Cl}^{-}$(e), $\mathrm{SO}_{4}{ }^{2-}$ (f), $\mathrm{HCO}_{3}{ }^{-}$(g), and total salt (h) over a two-year period within the upper 20 -cm surface layer of four treatments. $*$ indicates significant difference between years at $P<0.05$ level. Different lowercase letters indicate significant differences between years at $P<0.05$ level in the T1 treatment. Bars mean standard errors. 
There were no statistically significant changes in soil $\mathrm{Cl}^{-}$and $\mathrm{HCO}_{3}{ }^{-}$contents over the two-year period in the $\mathrm{T} 2$ and $\mathrm{T} 3$ treatments, or in the $\mathrm{pH}$ and total salt content in the $\mathrm{T} 3$ treatment (Fig. 4). The contents of $\mathrm{K}^{+}, \mathrm{Na}^{+}$, and $\mathrm{SO}_{4}{ }^{2-}$ significantly increased over the two-year period in the T2 and $\mathrm{T} 3$ treatments, while $\mathrm{Ca}^{2+}$ and $\mathrm{Mg}^{2+}$ contents significantly decreased in the $\mathrm{T} 2$ and T3 treatments. These results suggest that $S$. salsa absorbed $\mathrm{Ca}^{2+}$ and $\mathrm{Mg}^{2+}$, but not $\mathrm{K}^{+}, \mathrm{Na}^{+}$, or $\mathrm{SO}_{4}{ }^{2-}$, which is not entirely surprising because large quantities of $\mathrm{K}^{+}, \mathrm{Na}^{+}$, and $\mathrm{SO}_{4}{ }^{2-}$ are present in salt dust. The contents of $\mathrm{K}^{+}, \mathrm{Na}^{+}, \mathrm{Cl}^{-}$, and $\mathrm{SO}_{4}{ }^{2-}$ were higher than those of $\mathrm{Ca}^{2+}, \mathrm{Mg}^{2+}$, and $\mathrm{HCO}_{3}{ }^{-}$in the $\mathrm{T} 1$ treatment, indicating that the saline-alkaline soil accumulated large quantities of $\mathrm{K}^{+}, \mathrm{Na}^{+}, \mathrm{Cl}^{-}$, and $\mathrm{SO}_{4}{ }^{2-}$ due to the reasons previously stated.

The contents of TN and TP significantly increased in most treatments except TP in T1 plots $(P<0.05)$ (Fig. 5). In the T2 and T3 treatments, TN and TP contents significantly increased over the two-year period $(P<0.05)$, while the SOC and TK contents had little or no changes (Fig. 4). The contents of SOC, TN, and TP significantly increased in the T4 treatment. Overall, the contents of SOC, TN, and TP exhibited large increases because of the growth of the $S$. salsa plants.
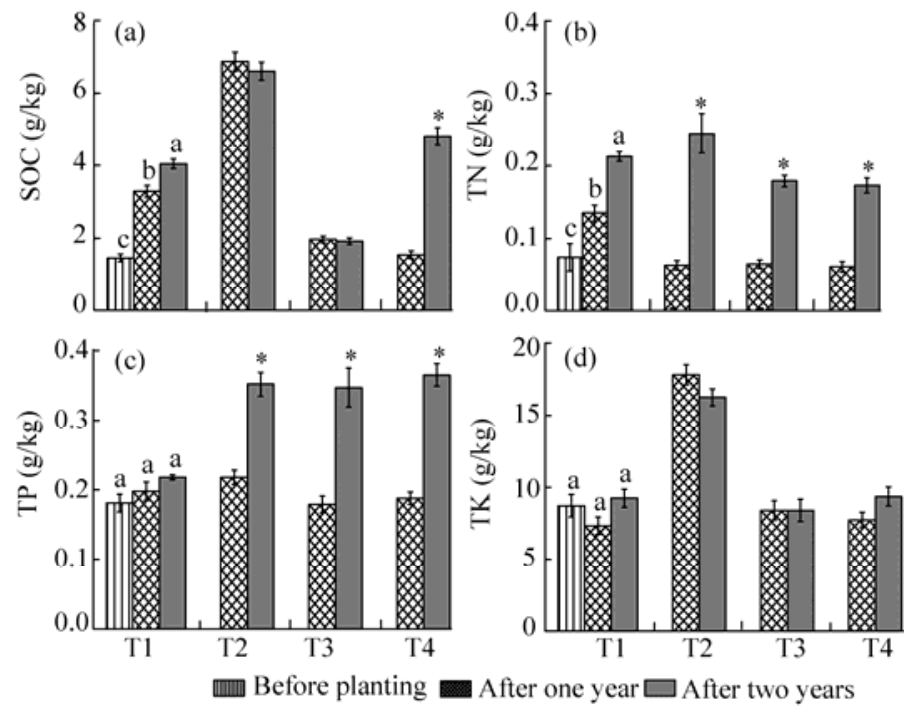

Fig. 5 Contents of soil organic carbon (SOC, a), total nitrogen $(\mathrm{TN}, \mathrm{b})$, total phosphorus (TP, c), and total potassium $(\mathrm{TK}, \mathrm{d}$ ) over a two-year period within the upper 20 -cm surface layer of four treatments. * indicates significant difference between years at $P<0.05$ level. Different lowercase letters indicate significant differences between years at $P<0.05$ level in the T1 treatment. Bars mean standard errors.

\subsection{Plant growth under different soil treatments}

Before August, the $S$. salsa plants grew well in response to the T4 treatment, with plant height, crown length, and width values that were significantly higher than those observed in the T1, T2, or T3 treatments (Table 2), which was confirmed by a visual evaluation at the end of the growing season (Fig. 6). This result indicates that the removal of the salt crust reduced salinity and improved the soil texture, being beneficial for plant growth. Since S. salsa is a halophyte that is tolerant to soil high salinity, it grew well in saline environment under the T1 treatment following an initial period of establishment.

The biomasses of individual plants grown under the $\mathrm{T} 1$ treatment were higher than those of plants grown under the T2 and T3 treatments (Fig. 7). Although the high salt content that was characteristic of the T1 treatment, limited germination and the survival of $S$. salsa seedlings was less competitive for water and nutrients, which resulted in a significant increase in the above-ground biomass. However, there were no significant differences in the root/shoot ratios among T1, T2, T3, and T4 plants. 
Table 2 Growth parameters of S. salsa at the second year of a two-year growth period in an undisturbed soil

\begin{tabular}{|c|c|c|c|c|c|c|c|c|c|}
\hline \multirow{2}{*}{ Soil type } & \multicolumn{3}{|c|}{8 July } & \multicolumn{3}{|c|}{28 July } & \multicolumn{3}{|c|}{14 August } \\
\hline & $\begin{array}{c}\text { Height } \\
(\mathrm{mm})\end{array}$ & $\begin{array}{c}\text { Crown } \\
\text { length }(\mathrm{mm})\end{array}$ & $\begin{array}{c}\text { Crown } \\
\text { width }(\mathrm{mm})\end{array}$ & $\begin{array}{c}\text { Height } \\
(\mathrm{mm})\end{array}$ & $\begin{array}{c}\text { Crown } \\
\text { length }(\mathrm{mm})\end{array}$ & $\begin{array}{c}\text { Crown } \\
\text { width }(\mathrm{mm})\end{array}$ & $\begin{array}{c}\text { Height } \\
(\mathrm{mm})\end{array}$ & $\begin{array}{c}\text { Crown } \\
\text { length }(\mathrm{mm})\end{array}$ & $\begin{array}{c}\text { Crown } \\
\text { width }(\mathrm{mm})\end{array}$ \\
\hline $\mathrm{T} 1$ & $12.7^{\mathrm{c}}$ & $20.1^{\mathrm{b}}$ & $20.4^{\mathrm{b}}$ & $23.2^{\mathrm{b}}$ & $38.4^{\mathrm{a}}$ & $26.2^{\mathrm{b}}$ & $36.7^{b}$ & $50.9^{\mathrm{a}}$ & $48.3^{\mathrm{a}}$ \\
\hline $\mathrm{T} 2$ & $21.1^{\mathrm{b}}$ & $19.1^{\mathrm{b}}$ & $20.5^{\mathrm{b}}$ & $26.1^{\mathrm{b}}$ & $25.8^{\mathrm{b}}$ & $26.2^{\mathrm{b}}$ & $37.4^{\mathrm{b}}$ & $31.7^{\mathrm{b}}$ & $30.8^{\mathrm{b}}$ \\
\hline $\mathrm{T} 3$ & $22.7^{\mathrm{b}}$ & $19.8^{\mathrm{b}}$ & $20.3^{\mathrm{b}}$ & $29.8^{\mathrm{b}}$ & $25.6^{\mathrm{b}}$ & $26.3^{\mathrm{b}}$ & $39.9^{\mathrm{b}}$ & $31.6^{\mathrm{b}}$ & $33.9^{\mathrm{b}}$ \\
\hline $\mathrm{T} 4$ & $25.7^{\mathrm{a}}$ & $25.8^{\mathrm{a}}$ & $24.3^{\mathrm{a}}$ & $37.3^{\mathrm{a}}$ & $27.1^{\mathrm{b}}$ & $28.1^{\mathrm{a}}$ & $56.3^{\mathrm{a}}$ & $32.1^{\mathrm{b}}$ & $36.2^{\mathrm{b}}$ \\
\hline
\end{tabular}

Note: T1, the crust layer removed and the soil surface left undisturbed; T2, a 40-cm surface slag layer; T3, a 20-cm slag layer placed below a $20-\mathrm{cm}$ sandy soil layer; T4a $40-\mathrm{cm}$ surface sandy soil layer. Different lowercase letters in the same column indicate significant differences among four treatments at $P<0.05$ level.

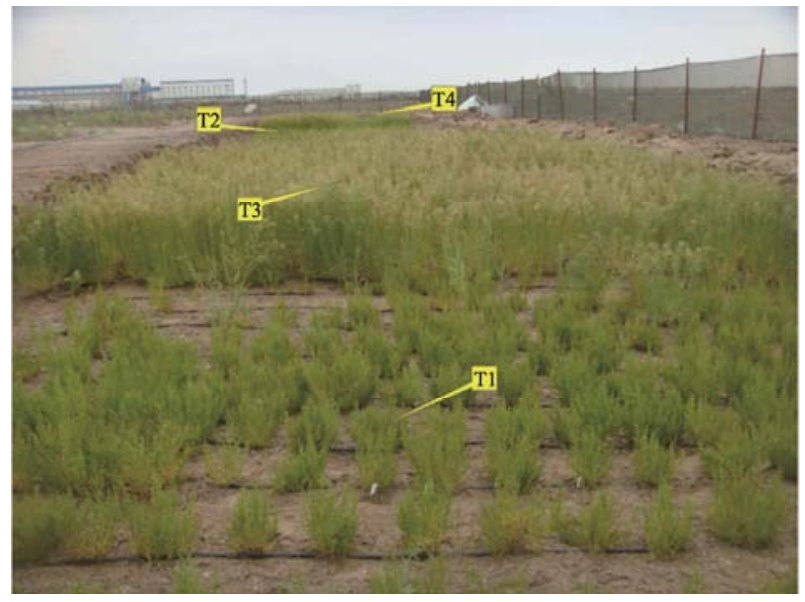

Fig. 6 Growth of Suaeda salsa under four treatments
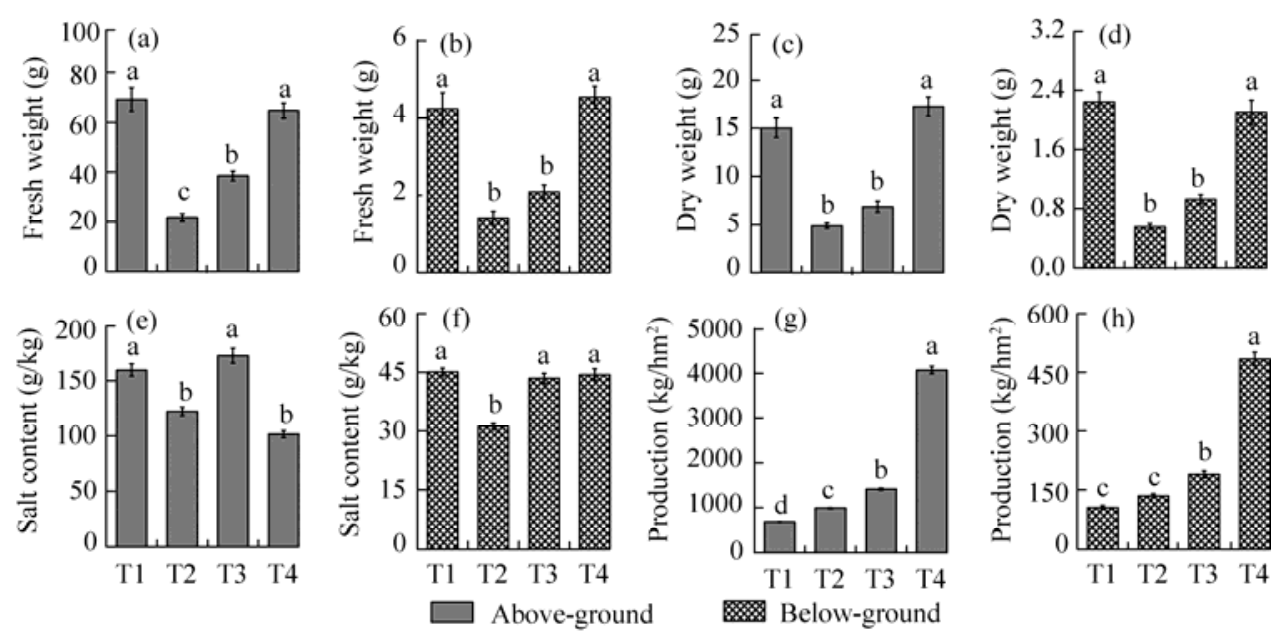

Fig. 7 Comparison of Suaeda salsa biomass and salt contents under four treatments. Different lowercase letters indicate significant differences among four treatments at $P<0.05$ level. Bars mean standard errors.

\subsection{Salt absorption capacity and salt absorption percentage observed for $\boldsymbol{S}$. salsa}

The salt absorption capacity and salt absorption percentage of $S$. salsa measured in the four treatments ranged from $120-460 \mathrm{~kg} / \mathrm{hm}^{2}$ and $9 \%-15 \%$, respectively (Fig. 8). The salt absorption capacity was greater for plants grown under the $\mathrm{T} 4$ treatment than under the other three treatments. Plants grown under the T1 and T2 treatments contained the smallest quantities of salts absorbed by the plant (Fig. 8c). The salt contents of different ions that were taken up by $S$. salsa are presented in Figure 9. It was found that $\mathrm{K}^{+}, \mathrm{Na}^{+}, \mathrm{Cl}^{-}$, and $\mathrm{SO}_{4}{ }^{2-}$ readily accumulated in both the above- and below-ground components of $S$. salsa, with the above-ground plant components 
accumulating larger salt quantities than the below-ground components. The larger quantities of these ions particularly in the above-ground components mimicked the relatively large quantities of $\mathrm{K}^{+}, \mathrm{Na}^{+}, \mathrm{Cl}^{-}$, and $\mathrm{SO}_{4}{ }^{2-}$ salts that were characteristic of the soil at this location and were represented in the $\mathrm{T} 1$ treatment. The $\mathrm{Ca}^{2+}$ content within the above-ground components of $\mathrm{S}$. salsa was representative of the surface salt content within the upper $20-\mathrm{cm}$ surface layer of the four treatments. The $\mathrm{Mg}^{2+}$ content was generally larger than the soil $\mathrm{Mg}^{2+}$ content in the upper $20-\mathrm{cm}$ surface layers of the four treatments, except for the soil $\mathrm{Mg}^{2+}$ content in the $\mathrm{T} 1$ treatment before planting.
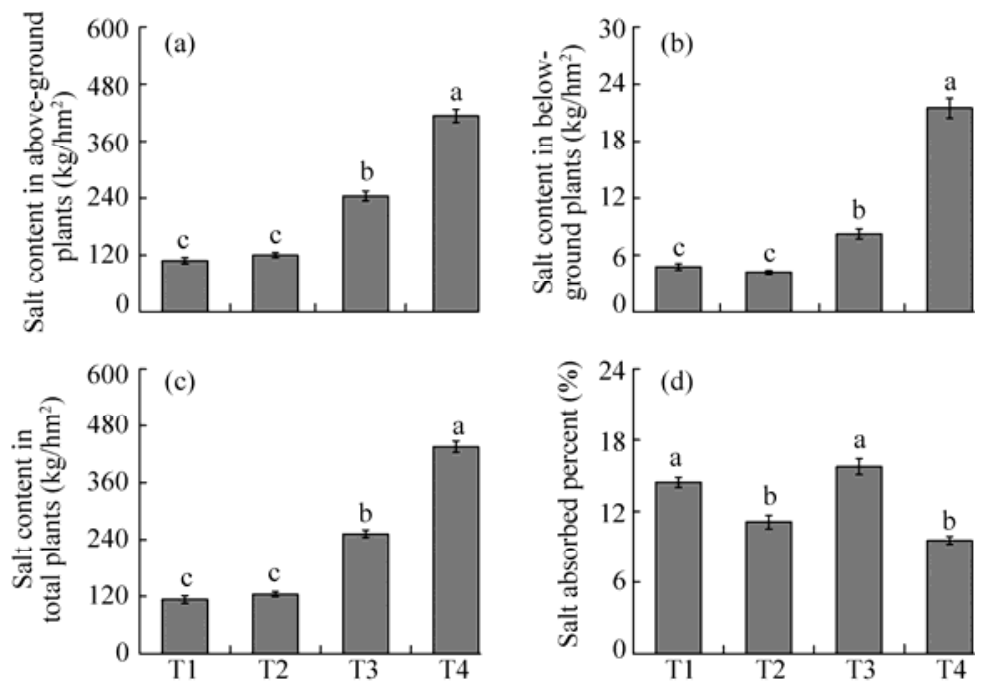

Fig. 8 Salt contents in s (a), below-ground plants (b), and total plants (c), and the salt absorption percent (d) of dry weight of Suaeda salsa at the second year of a two-year growth period under four treatments. Different lowercase letters indicate significant differences among four treatments at $P<0.05$ level. Bars mean standard errors.

\section{Discussion and conclusions}

\subsection{Effect of $S$. salsa growth on saline soil}

Many halophytic plant species grow naturally in high-salinity areas, and can absorb salt from the rhizosphere (Song and Wang, 2015; Song et al., 2017). Ravindran et al. (2007) reported that the halophytes Suaeda maritima and Sesuvium portulacastrum (Aizoaceae) had greater accumulations of salt within their tissues, and caused greater salt reductions within the soil, than four other vegetative species. Rabhi et al. (2009) compared S. portulacastrum with two other halophytes, Abutilon indicum and Suaeda fruticosa, with respect to their ability to desalinate saline soils, and they found that of the three species studied, S. portulacastrum was the most effective species to grow when leaching salts from the rhizosphere in arid and semi-arid regions. The results of our study indicate that $S$. salsa exhibits similar soil salinity and alkalinity reduction characteristics. The salt absorption percentage for $S$. salsa ranged from $9 \%$ to $15 \%$, and total salt contents decreased from 355.27 to $95.73 \mathrm{mg} / \mathrm{g}$. There were also an increasing trend in SOC, TN, and TP contents in the T1 treatment. Several factors may be responsible for the above results, including changes in soil microbe populations (Marschner and Römheld, 1996), increases in root activity in the rhizosphere (Ma and Palada, 2006; Li et al., 2011), increases in litterfall deposition and the uptake of soil nutrients by plant roots (Bochet et al., 1999; Zaady et al., 2001; Li et al., 2015), and changes in the biogeochemical cycle (Schlesinger et al., 1996; Li et al., 2014).

The SOC and TK contents did not increase in response to the T2 and T3 treatments, although there were significant changes in the TN and TP contents that may be partly attributed to the high SOC and TK contents that resulted from the addition of slag in the T2 treatment (Table 1). Total soil salt content increased with planting year in the T4 treatment, possibly because of the 

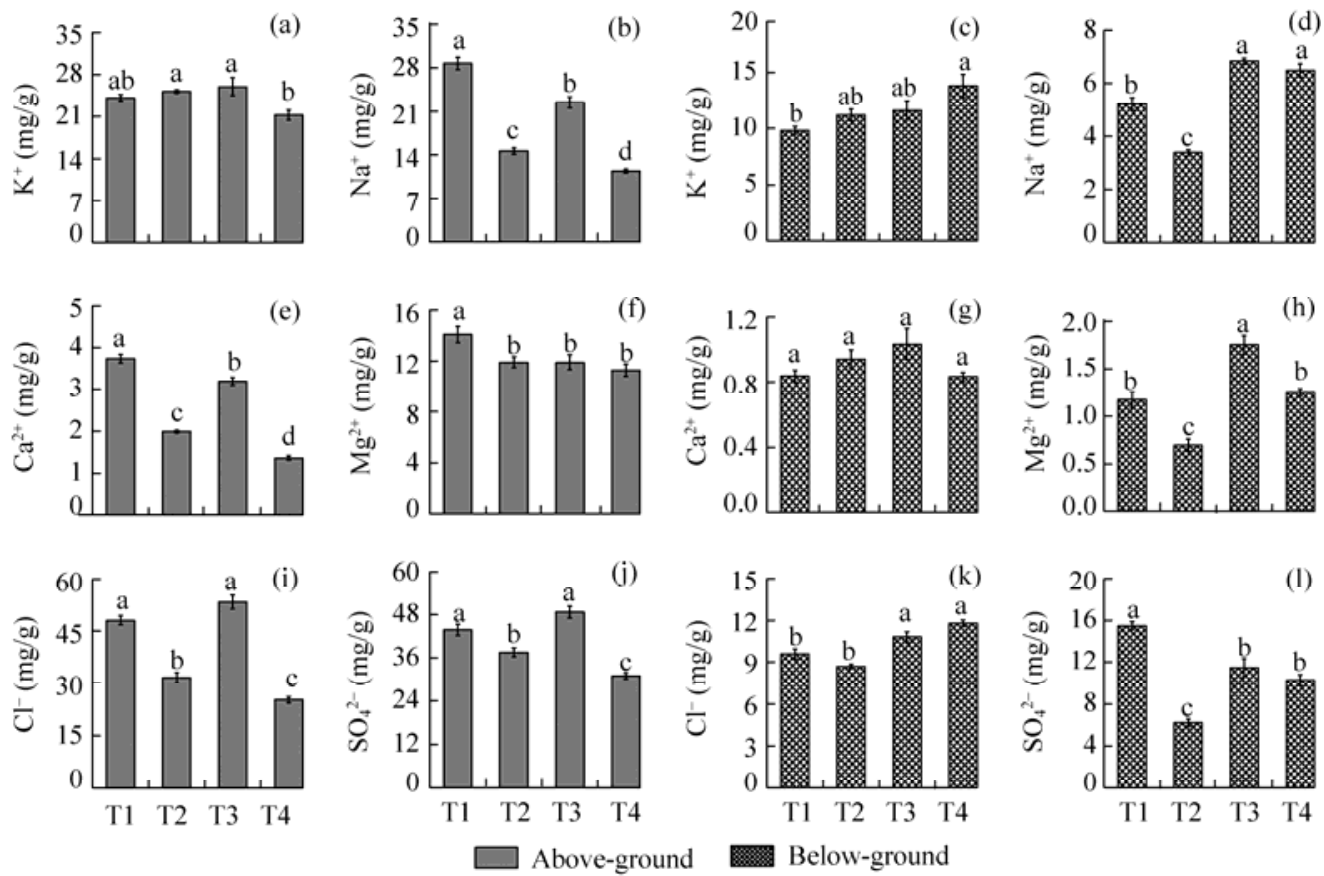

Fig. 9 Contents of $\mathrm{K}^{+}(\mathrm{a}), \mathrm{Na}^{+}(\mathrm{b}), \mathrm{Ca}^{2+}$ (e), $\mathrm{Mg}^{2+}$ (f), $\mathrm{Cl}^{-}$(i), and $\mathrm{SO}_{4}{ }^{2-}$ (j) within the above-ground components and contents of $\mathrm{K}^{+}(\mathrm{c}), \mathrm{Na}^{+}(\mathrm{d}), \mathrm{Ca}^{2+}(\mathrm{g}), \mathrm{Mg}^{2+}(\mathrm{h}), \mathrm{Cl}^{-}(\mathrm{k})$, and $\mathrm{SO}_{4}{ }^{2-}$ (l) within the below-ground components of Suaeda salsa at the second year of a two-year growth period under four treatments. Different lowercase letters indicate significant differences among four treatments at $P<0.05$ level. Bars mean standard errors.

deposition of salt dust and the accumulation of salt at the soil surface derived from the high evaporative demand that is characteristic of the area. In support of this explanation, the quantities of salt that had accumulated in the surface soil layer $(0-20 \mathrm{~cm})$ were larger than that of salt absorbed by the plants, moreover, it has been found that $S$. salsa not only absorbs salt from the rhizosphere, but also from atmospheric dust. Therefore, we speculated that planting and harvesting of $S$. salsa in the Lop Nur area might decrease the salt contents and would beneficial for plant reconstruction and ecological restoration in the highly saline soil of the area.

\subsection{Effect of saline soil on plant growth}

High soil salinity is characterized by large amounts of $\mathrm{Na}^{+}, \mathrm{Mg}^{2+}, \mathrm{Ga}^{2+}, \mathrm{Cl}^{-}, \mathrm{HCO}_{3}^{-}$, and $\mathrm{SO}_{4}{ }^{2-}$ ions within the soil. These ions are major abiotic stressors that reduce plant productivity, affect crop germination and density, inhibit vegetative development, and in the most serious cases, lead to generalized plant death (Xu et al., 2016; Zhou et al., 2016; Song et al., 2017). Suaeda salsa plants grew well under the T4 treatment, with better growth than those grown under the T1, T2, and $\mathrm{T} 3$ treatments. This result indicates that growth improvements result from an improved plant environment, where there is less stress placed on the plants because salinity has been reduced. Meanwhile, large pores, which were characteristic of the slag in the T2 and T3 treatments, resulted in a reduced capability of the plants to retain water.

\subsection{Plant-soil interactions}

The soil provides a reserve of water and nutrients necessary for plant growth. At the same time, plants exert a significant impact on the physical and chemical properties in soil (Dagar et al., 2001). In a saline soil environment, halophytes can absorb and accumulate salts, and over time may gradually reduce soil salinity. Planting halophytes can increase soil nutrient and fertility levels over time, because root exudates, rhizosphere microorganisms, and litter decomposition have a gradual impact on the soil environment.

It was found that the salt absorption capacity of $S$. salsa ranged from 120 to $460 \mathrm{~kg} / \mathrm{hm}^{2}$ in this 
area. This absorption capacity was much smaller than that reported in a study performed in Karamay, China, where S. salsa plants absorbed up to approximately $5000 \mathrm{~kg} / \mathrm{hm}^{2}$ of salt from the soil (Zhao et al., 2013). The salt absorption capacity was greatest under the T4 treatment (Fig. 7), which was largely due to the large amount of biomass produced under the T4 treatment. Significant quantities of $\mathrm{K}^{+}, \mathrm{Na}^{+}, \mathrm{Cl}^{-}$, and $\mathrm{SO}_{4}{ }^{2-}$ accumulated within both the above- and below-ground parts of the $S$. salsa plants, and were the predominant ions absorbed by $S$. salsa, while $\mathrm{Ca}^{2+}$ ions were absorbed in much lower quantities (Fig. 8).

Meanwhile, planting $S$. salsa plays an important role in the improvement of saline-alkaline soil. Although high salinity and alkalinity present within the soil of the T1 treatment strongly affected plant germination and survival of $S$. salsa, the remaining plants that survived developed a large above-ground part. This may be partly attributed to $S$. salsa being a euhalophyte, with a strong salt tolerance capability (Song et al., 2011; Zhao et al., 2013; Song and Wang, 2015).

\subsection{Sustainability of planting $S$. salsa in the Lop Nur}

Comparing the four treatments by plant growth, soil improvement, and the costs required (Table 3 ), we found that the T1 treatment was sustainable because it was the cheapest and the best soil improvement, although the germination rate was low. With the decreases in soil salinity, germination and growth of halophytes should be improved. Therefore, planting S. salsa in the highly saline soils of Lop Nur after removing the salt layer may gradually reduce soil salinity and increase the soil nutrient content. Growing plants of this species may also result in subsequent improvements within the soil environment, and would therefore be beneficial for plant reconstruction and ecological restoration in the Lop Nur area as well as similar areas throughout the world.

Table 3 Plant growth, soil improvement, and the costs required for the four treatments

\begin{tabular}{|c|c|c|c|c|}
\hline Treatment & Plant growth & Soil improvement & Cost (Chinese Yuan $/ \mathrm{km}^{2}$ ) & Sustainability \\
\hline $\mathrm{T} 1$ & $\begin{array}{l}\text { The germination rate was } \\
\text { the lowest, although } \\
\text { surviving plants grew well }\end{array}$ & $\begin{array}{c}\text { Soil nutrients } \\
\text { accumulated } \\
\text { significantly and salinity } \\
\text { was meliorated }\end{array}$ & $\begin{array}{l}\text { No cost other than the cost of } \\
\text { seeds, water, and labor }\end{array}$ & Sustainable \\
\hline $\mathrm{T} 2$ & $\begin{array}{l}\text { The germination rate was } \\
\text { higher in } \mathrm{T} 2 \text { treatment than } \\
\text { in } \mathrm{T} 1 \text { treatment, but } \\
\text { surviving plants grew } \\
\text { poorly }\end{array}$ & $\begin{array}{l}\text { Soil nutrients and } \\
\text { salinity accumulated }\end{array}$ & $\begin{array}{l}\text { Fewer costs, except for the cost of } \\
\text { seeds, water, labor, and the cost of } \\
\text { transporting the slag (about } 8 \times 10^{6} \text { ) }\end{array}$ & Unsustainable \\
\hline $\mathrm{T} 3$ & $\begin{array}{l}\text { The germination rate was } \\
\text { higher in T3 treatment than } \\
\text { in T2 treatment, and the } \\
\text { surviving plants grew well }\end{array}$ & $\begin{array}{l}\text { Soil nutrients and } \\
\text { salinity accumulated }\end{array}$ & $\begin{array}{l}\text { Higher costs, including the cost of } \\
\text { seeds, water, and labor, in addition } \\
\text { to the cost of transporting the slag } \\
\text { and soil, which was substantial } \\
\text { (about } 24 \times 10^{6} \text { ) }\end{array}$ & Unsustainable \\
\hline $\mathrm{T} 4$ & $\begin{array}{l}\text { The germination rate was } \\
\text { the highest, and all the } \\
\text { surviving plants grew well. } \\
\text { Thus, the production was } \\
\text { the highest }\end{array}$ & $\begin{array}{l}\text { Soil nutrients and } \\
\text { salinity accumulated }\end{array}$ & $\begin{array}{l}\text { The highest cost, which included } \\
\text { the cost of seeds, water, and labor, } \\
\text { in addition to the cost of } \\
\text { transporting the slag and soil } \\
\left.\text { (about } 40 \times 10^{6}\right)\end{array}$ & Unsustainable \\
\hline
\end{tabular}

\section{Acknowledgments}

This study was supported by the Youth Innovation Promotion Association of Chinese Academy of Sciences (2017476), the National High-level Personnel Special Support Program, Xinjiang Youth Science and Technology Innovation Leader Project (QN2016BS0162), the National Key Research and Development Program (2017YFSF03024105), the National Natural Science Foundation of China (31700423, 31300449), and the Xinjiang Uygur Autonomous Region Science and Technology Support Project (201433101).

\section{References}

Ashraf M, Athar H R, Harris P J C, et al. 2008. Some prospective strategies for improving crop salt tolerance. Advances in Agronomy, 97: 45-110.

Bochet E, Rubio J L, Poesen J. 1999. Modified topsoil islands within patchy Mediterranean vegetation in SE Spain. CATENA, 
38(1): 23-44.

Chen P C. 1936. Lop Nor and Lop Desert. Acta Geographica Sinica, 3(1): 19-49. (in Chinese)

Cheng S, Yang Z, Wang M J, et al. 2014. Salinity improves chilling resistance in Suaeda salsa. Acta Physiologiae Plantarum, 36(7): 1823-1830.

Dagar J C, Singh G, Singh N T. 2001. Evaluation of forest and fruit trees used for rehabilitation of semiarid alkali-sodic soils in India. Arid Land Research and Management, 15(2): 115-133.

Darwish T, Atallah T, El Moujabber M, et al. 2005. Salinity evolution and crop response to secondary soil salinity in two agro-climatic zones in Lebanon. Agricultural Water Management, 78(1-2): 152-164.

Duan D Y, Li W Q, Liu X J, et al. 2007. Seed germination and seedling growth of Suaeda salsa under salt stress. Annales Botanici Fennici, 44(3): 161-169.

Fresenius W, Quentin K E, Schneider W. 1988. Water Analysis: A Practical Guide to Physico-Chemical, Chemical and Microbiological Water Examination and Quality Assurance. Gledhill A, Holland R, Oliver T J, trans. Berlin Heidelberg: Springer-Verlag, 87-89.

Khan M A, Weber D J. 2006. Ecophysiology of High Salinity Tolerant Plants. Dordrecht: Springer, 56-58.

Li C J, Li Y, Ma J. 2011. Spatial heterogeneity of soil chemical properties at fine scales induced by Haloxylon ammodendron (Chenopodiaceae) plants in a sandy desert. Ecological Research, 26(2): 385-394.

Li C J, Shi X, Lei J Q, et al. 2014. The scale effect on the soil spatial heterogeneity of Haloxylon ammodendron (C. A. Mey.) in a sandy desert. Environmental Earth Sciences, 71(9): 4199-4207.

Li C J, Lei J Q, Zhao Y, et al. 2015. Effect of saline water irrigation on soil development and plant growth in the Taklimakan Desert Highway Shelterbelt. Soil and Tillage Research, 146: 99-107.

Liang Y C, Si J, Nikolic M, et al. 2005. Organic manure stimulates biological activity and barley growth in soil subject to secondary salinization. Soil Biology and Biochemistry, 37(6): 1185-1195.

Ma C H, Palada M C. 2006. Fertility management of the soil-rhizosphere system for efficient fertilizer user in vegetable production. In: International Workshop on Sustained Management of the Soil-Rhizosphere System for Efficient Crop Production and Fertilizer Use. Shanhua, Tainan, Taiwan, China: National Chung Hsing University, 16-20.

Marschner H, Römheld V. 1996. Root-induced changes in the availability of micronutrients in the rhizosphere. In: Waisel Y, Eshel A, Kafkafi U. Plant Roots: the Hidden Half. New York: Marcel-Dekker, 557-579.

Metternicht G I, Zinck J A. 2003. Remote sensing of soil salinity: potentials and constraints. Remote Sensing of Environment, 85(1): 1-20.

Miyamoto S, Chacon A, Hossain M, et al. 2005. Soil salinity of urban turf areas irrigated with saline water: I. Spatial variability. Landscape and Urban Planning, 71(2-4): 233-241.

Mondal M K, Bhuiyan S I, Franco D T. 2001. Soil salinity reduction and prediction of salt dynamics in the coastal ricelands of Bangladesh. Agricultural Water Management, 47(1): 9-23.

Nelson D W, Sommers L E. 1982. Total carbon, organic carbon, and organic matter. In: Page A L, Miller R H, Keeney D R. Methods of Soil Analysis ( $2^{\text {nd }}$ ed.). Madison, WI: Agronomy Society of America and Soil Science Society of America, $535-579$.

Patnaik P. 1997. Handbook of Environmental Analysis: Chemical Pollutants in Air, Water, Soil, and Solid Wastes. Boca Raton: CRC Publisher, 215-220.

Rabhi M, Hafsi C, Lakhdar A, et al. 2009. Evaluation of the capacity of three halophytes to desalinize their rhizosphere as grown on saline soils under nonleaching conditions. African Journal of Ecology, 47(4): 463-468.

Ravindran K C, Venkatesan K, Balakrishnan V, et al. 2007. Restoration of saline land by halophytes for Indian soils. Soil Biology and Biochemistry, 39(10): 2661-2664.

Schlesinger W H, Raikes J A, Hartley A E, et al. 1996. On the spatial pattern of soil nutrients in desert ecosystems. Ecology, 77(2): 364-374.

Song J, Shi G W, Gao B, et al. 2011. Waterlogging and salinity effects on two Suaeda salsa populations. Physiologia Plantarum, 141(4): 343-351.

Song J, Wang B S. 2015. Using euhalophytes to understand salt tolerance and to develop saline agriculture: Suaeda salsa as a promising model. Annals of Botany, 115(3): 541-553.

Song J, Shi W W, Liu R R, et al. 2017. The role of the seed coat in adaptation of dimorphic seeds of the euhalophyte Suaeda salsa to salinity. Plant Species Biology, 32(2): 107-114.

Tejada M, Gonzalez J L. 2005. Beet vinasse applied to wheat under dryland conditions affects soil properties and yield. European Journal of Agronomy, 23(4): 336-347.

Tejada M, Garcia C, Gonzalez J L, et al. 2006. Use of organic amendment as a strategy for saline soil remediation: Influence on 
the physical, chemical and biological properties of soil. Soil Biology and Biochemistry, 38(6): 1413-1421.

Tian C Y, Feng G, Li X L, et al. 2004. Different effects of arbuscular mycorrhizal fungal isolates from saline or non-saline soil on salinity tolerance of plants. Applied Soil Ecology, 26(2): 143-148.

Uddin M K, Juraimi A S, Ismail M R, et al. 2009. Growth response of eight tropical turfgrass species to salinity. African Journal of Biotechnology, 8: 5799-5806.

Wang F X, Xu Y G, Wang S, et al. 2015. Salinity affects production and salt tolerance of dimorphic seeds of Suaeda salsa. Plant Physiology and Biochemistry, 95: 41-48.

Xu Y G, Liu R R, Sui N, et al. 2016. Changes in endogenous hormones and seed-coat phenolics during seed storage of two Suaeda salsa populations. Australian Journal of Botany, 64(4): 325-332.

Yavitt J B, Harms K E, Garcia M N, et al. 2009. Spatial heterogeneity of soil chemical properties in a lowland tropical moist forest, Panama. Australian Journal of Soil Research, 47(7): 674-687.

Zaady E, Offer Y Z, Shachak M. 2001. The content and contributions of deposited aeolian organic matter in a dry land ecosystem of the Negev Desert, Israel. Atmospheric Environment, 35(4): 769-776.

Zhang H Y, Zhao K F. 1998. Effects of salt and water stresses on osmotic adjustment of Suaeda salsa seedlings. Acta Botanica Sinica, 40(1): 56-61.

Zhao H L, Zhou R L, Zhang T H, et al. 2006. Effects of desertification on soil and crop growth properties in Horqin sandy cropland of Inner Mongolia, north China. Soil Tillage Research, 87: 175-185.

Zhao K F. 1991. Desalinization of saline soils by Suaeda salsa. Plant and Soil, 135: 303-305.

Zhao K F, Fan H, Jiang X Y, et al. 2002. Critical day-length and photoinductive cycles for the induction of flowering in halophyte Suaeda salsa. Plant Sciences, 162(1): 27-31.

Zhao K F, Fan H, Zhou S, et al. 2003. Study on the salt and drought tolerance of Suaeda salsa and Kalanchoe claigremontiana under iso-osmotic salt and water stress. Plant Sciences, 165(4): 837-844.

Zhao Z Y, Zhang K, Wang P, et al. 2013. Desalination effect of halophytes in heavily salinized soil of Karamay, Xinjiang, China. Journal of Desert Research, 33(5): 1420-1425. (in Chinese)

Zhou J C, Fu T T, Sui N, et al. 2016. The role of salinity in seed maturation of the euhalophyte Suaeda salsa. Plant Biosystems, 150(1): 83-90.

Zhu Z, Chen J, Zheng H L. 2012. Physiological and proteomic characterization of salt tolerance in a mangrove plant, Bruguiera gymnorrhiza (L.) Lam. Tree Physiology, 32(11): 1378-1388. 